\title{
Defining Objectivity within Journalism
}

\author{
An Overview
}

\author{
Charlotte Wien
}

\begin{abstract}
The article seeks the roots of the journalistic concept of objectivity in various theoretical schools. It argues that the concept of objectivity in journalism originates in the positivistic tradition and, furthermore, that it is strongly related to tan earlier theoretical school within historiography. Journalism has made several attempts have been made by journalism to break free of the positivistic objectivity paradigm, none of them very successful, however. The paper discusses each of these attempts. Finally, using the concept of objectivity as a prism, the paper sketches out what might be termed a landscape of journalism theory.
\end{abstract}

Key Words: objectivity, positivism, journalism, history

\section{Introduction}

Journalism derives a great deal of its legitimacy from the postulate that it is able to present true pictures of reality. No one would have use for journalism if the journalists themselves asserted that the dissemination of news consisted of false pictures of unreality. Concepts such as 'truth' and 'reality' cannot be separated from the concept of objectivity. Hence, if one can speak of a paradigm within journalism, we might see such a paradigm in the requirement for objectivity in disseminating news. But it is one thing to operate with objectivity as a beacon, and something else to operationalise objectivity in the everyday task of journalism.

Within journalism, there exist several schools which have attempted to operationalise the concept of objectivity: e.g. Mainstream Journalism, Scientific Journalism, New Journalism and Precision Journalism (including Computer-Assisted Reporting). To operationalise concepts demands either that one thinks for oneself or that one borrows the ideas of others. The latter is by far the most frequent and this is what usually occurs when practitioners - such as journalists - need a theory.

The purpose of this article is precisely to show how the aforementioned schools within journalism have attempted to operationalise the concept of objectivity by borrowing bits and pieces from the theory of science. I will pursue the journalistic concept of objectivity and using the concept of objectivity as a prism; will proceed to discuss the 
various journalistic tendencies and their kinship with various scientific theoretical schools. With a point of departure in the concept of objectivity, I will endeavour to sketch out what could be termed the landscape of journalism theory.

One can assert that this effort is a waste of time: journalism is a craft and not a science, and is therefore unconcerned with trends in the theory of science, and that every association between the various scientific theoretical tendencies and journalism is pure fantasy. On further examination, however, this position proves untenable. First, scientific trends run through all the nooks and crannies of society and its everyday thought. Second, journalism utilises concepts such as 'truth', 'reality' and 'objectivity' and, as a professional discipline, must therefore reflect upon what these concepts mean and how they are to be operationalised, unless journalism is willing to admit that it is totally devoid of ideas.

\section{Positivism is Dead! Long Live Positivism!}

Journalism arose as a true profession in the end of the $1800 \mathrm{~s}$. The first university course in journalism was offered at the University of Missouri (at Columbia) from 1879-1884, and the first trade union of journalists was founded in England in 1883 (Encyclopaedia Britannica 2003). At that time, the discipline resembled to a great degree what Hindman, using a contemporary term, calls 'mainstream journalism', which remains the form of journalism which the vast majority of journalists carry out:

Mainstream Journalism is represented by professional norms and uses certain techniques of news-gathering and construction. A mainstream journalist tries to be objective, remains distant from her or his subject, finds information in official places, and presents that information in particular ways (Hindman 1998:177)

Just 40 years earlier, positivism had been 'christened' and described as a scientific theoretical school by August Comte (Kjørup 2000:289). I argue here that most journalism, as is the case with most of the scientific world, continues to utilise a positivist concept of objectivity.

Positivism is appealing in its common-sense approach to knowledge: the only thing we can know something about is that which we can immediately know via our senses; hence, it is only via the senses that certain knowledge can be achieved. When certain knowledge has been achieved, this knowledge is like building blocks in the total sum of human knowledge (Hackett and Zhao 1998:109-110; Kjørup 2000:288-307).

The positivist concept of objectivity is binary: one is either objective or one is subjective. To be subjective is to say that one's own assessments (attitudes and values) have influence on knowledge. To be objective is to say that one is content to present that which is not affected by one's own assessments, i.e., the facts. Facts are what can be experienced directly, that which others would be able to know in precisely the same way. And the truth value of a fact is not under discussion. If one is content to communicate a fact, one is by definition objective. Hence, it is a precondition of positivism that one can distinguish between facts and opinions.

In a recent textbook on journalism, in a chapter appropriately entitled 'Fact vs. Opinion', one can read:

In the previous examples, the writers reported the sights, sounds and smells they observed. Those observations were factual - evidence of conditions that anyone on the scene could have observed. The writers let the readers form their own opinions (Rich 2000:85). 
The assumption of the possibility of unequivocally distinguishing between facts and opinions emerges clearly and accords precisely with the positivistic way of understanding the concept of objectivity: everything that the journalist can and must write is that which he can directly observe and that which is factual. The journalist must keep his or her own opinions outside of the product and allow the readers to form their own opinions on the basis of the facts which the journalist has presented.

There also exists a Danish version of this article of faith, i.e., that it is possible for the journalist to present the facts and only the facts and allow readers to formulate their own opinions. Ufer writes with a powerful quote from his old own master:

Goddamnit, you must not tell people whether a fire is 'terrible' or not. [...] Just report, damnit! People won't give a shit about what you think. They want to know what has happened! (Ufer 2001:39, emphasis in original, my translation from the Danish).

Ufer's old master thus demanded of his students that they be able to distil their own person out of the journalistic product and thus simply report what has happened (the facts) and keep their own opinions out of the product.

In practice, however, it is not so simple to distinguish between facts and opinions:

The critique of the concept of objectivity in this model builds precisely upon the idea of what we now know, with rather great certainty, namely, that facts do not speak for themselves, that facts in the meaning of recordability, are only a surface, which is simply incomprehensible if not explained with underlying, but often not immediately recordable associations (Andrén, Hemánus et al. 1979:11; my translation from the Danish).

The problem is that the journalist must undertake a choice of context in which to place the facts. And this choice is his own subjective choice. This is an understanding which journalism, like science, has found it very difficult to tackle. Hence, much of the more thoughtful literature about and textbooks in journalism also maintain a distinction between facts and opinions, though with certain reservations in some cases. For instance, in a textbook in journalistic source criticism, Thurén writes:

It is thus difficult to distinguish between opinions and descriptions of reality. The question is whether it is at all meaningful. Is it not simply a question of an abstract construction without practical significance? We must conclude this chapter by presenting three arguments for maintaining the distinction between facts and opinions (1986:11; my translation from the Swedish).

Thurén goes on to present three explanations for why this distinction is necessary: (1) it is of great value in political debates; (2) in order to avoid the belief that opinions can be judged for their truth value; and (3) in order to emphasise that people's views of reality are affected by their opinions. However, this does not make Thurén's hypothesis any more correct. Others, well knowing it to be problematic, choose to utilise a distinction between facts and opinion. Hence, Schudson, in his doctoral dissertation on the history of the concept of objectivity in journalism, writes:

I began this study to explore the ideal that facts should be separated from values in social science. I did so because I distrusted the cant of 'value-free sociology' and its corollaries. [...] Still, I could not embrace any glib rejection of the valuefree ideal. The ideal is so powerful that its critics often believe in it despite themselves. [...] I shall define 'objectivity' as the view that one can and should separate facts from values (Schudson 1990:2-3). 
Schudson's attempt to wriggle out of the seductive positivistic concept of objectivity is an experience which resonates with many researchers, and perhaps also some journalists.

\section{Writing History and Journalism Research}

Let me dwell a bit more on several other interfaces between positivism and journalism. On two other very prominent points, journalism is affected by its positivist heritage: first, in its understanding of what constitutes the task of 'writing a story', and second, in its reliance on source criticism. Journalism has borrowed several features from the discipline of historiy. In the following, I will argue that the borrowings are the cast-offs of history.

Leopold von Ranke ${ }^{1}$, in his Geschichte der romanischen und germanischen Völker (1824) confronted the historiography of earlier eras. In opposition to the early historians, he wanted to write history 'Wie es eigentlich gewesen'.

The sentence should be understood as a breach with the chronicling (read: good stories) of earlier eras and certainly not as reality, as the historians of later eras understood it: they believed that the task of the discipline of history, according to Ranke, was to reconstruct the past with the help of the sources. The sources were, so to say, pieces of the puzzle of the past, and when collected in the right way, one would obtain a true and comprehensive picture of how things had really been. Up through the 1900s and especially in the $1960 \mathrm{~s}$, it became increasingly clear to the historians that this task was not only extremely tedious, but also impossible. The past is dead and gone, and as such, uninteresting. To concern oneself with the past is interesting only insofar as one has a problem which is relevant and interesting for the present (and/or the future). A contemporary understanding of the task of historical research would imply that the discipline of history should reconstruct the past in light of a contemporary problem (Hansen 1999).

Within journalism, the belief in the possibility of describing 'wie es eigentlich gewesen', appears ever more frequently. In the following, I will hold myself to two examples. They are both taken from the preface to books concerned with something in the past. The first example comes from the Swedish Eastern Europe correspondent Richard Swartz, who after covering Eastern Europe for nearly thirty years writes:

I therefore sat myself down at my desk and began to write down how it had been, for nearly thirty years in any case, before I, too, had forgotten it.

How it had really been... (Swartz 1996:7-8; translation from the Danish edition of the Swedish original).

Swartz thus sets for himself the rather imposing task of describing how it really was for 30 years of Eastern Europe's history. The second example is from Nybroe and Mylenberg's account of the Danish parliamentary election campaign of 2001:

Our goal in this book is to draw a more complete picture of the key Danish politicians during the campaign. To describe the reality that most of the voters, for good reason, did not know about when they cast their vote. This is the story of how politicians manipulate our reality and our perception of reality.

$[\ldots]$

We emphasise that this book is not the whole truth. There can have occurred a whole lot during the campaign which for different reasons we have not succeeded in discovering (Nybroe and Mylenberg 2002:8-9, emphasis in original, my translation from the Danish). 
Even though Nybroe and Mylenberg attempt a delimitation of the topic (how politicians manipulate our reality) and also express reservations about their own presentation (this book is not the whole truth), both books nevertheless attempt reconstructions of the past without any clear focal point in the present.

As mentioned above, journalism also borrows from the source criticism of positivist historical research: it is evident to everyone that not all sources are equally good i.e., possess equally great truth value - when one works with a journalistic product or with historical research. Kristian Erslev made himself into a spokesman for presenting a system of conceptual pairs which could be used to classify sources. The idea was that by determining the sources by type, one could assess the sources' relative truth value (Kjørup 2000:55).

Among historians, source classification up through the 1960s led to vehement discussions because it is not possible to undertake such a definitive classification of sources. The sources change role and function and must therefore also be classified differently depending on how they are used, i.e., dependent on the problem one is researching. This can be best illustrated with an example from my own teaching in source criticism for students of journalism. The students are shown an overhead diagram with the following text:

On Friday, February $6^{\text {th }}, 2004$, Charlotte had an apple with her, as she was going to teach source criticism. She had the apple while the journalism students took their seats. She ate the apple because she knew that it was healthy and because she wanted to use it to reveal the differences between material evidence ${ }^{2}$ and witnesses' accounts. Therefore she let the apple core remain on the table. ${ }^{3}$

It seems to be immediately evident that the apple core is a material evidence and the overhead a witnesses' account. This is not necessarily true, for if the piece of the past which must be elucidated is what took place in the concrete teaching hour, then the overhead can suddenly be viewed as material evidence. In other words, the sources are like the plastic fragments in a kaleidoscope: if one shakes them, they create a new pattern and their truth value changes. And this is approximately what happens with several of the other conceptual pairs in historical source criticism.

Probably the most popular conceptual pair from the positivist historical tradition used by journalists are the concepts of 'first-hand-' and 'second-hand witnesses'. The firsthand witness is the source who has been present at the event, while the second-hand witness has had the event related to him. The positivist historical tradition tends to view the first-hand witness as having the greatest (truth) value (Fink, Manniche et al. 1996:15). This way of assessing the quality of sources is, of course, unusable. For what if the first-hand witness to an event has no prerequisites and does not understand the concrete event? And what if the second-hand witness has in fact studied the event and collected and analyses innumerable testimonies about it?

Nevertheless, we can rediscover the naive faith that the first-hand witness has a higher truth value than the second-hand witness in the practical world of everyday journalism; this view is reflected especially in the work of war correspondents. Journalists who find themselves thousands of kilometres away from the actual battle are asked by the news reader in the studio to answer the question: 'What is happening right now?'. At times the journalist will have just landed in the area and has only just been able to don his bullet-proof vest. He is not a specialist in military tactics or in the region in which he find himself, and he can neither see or hear anything else than that which others with Internet connections might also access. That his report is nevertheless included in 
the evening news broadcast is due to the fact that he seems to be more convincing as first-hand witness than someone located in Copenhagen or in a provincial Danish town such as Odense.

Like researchers, however, journalists are not (all) empty-headed people, and attempts to renounce the positivist ideal of objectivity within scientific research has also left its traces in journalism.

\section{Accuracy, Fairness and Balance: Journalism Tries to Break with the Objectivity Paradigm}

The discussion of positivism which took place and continues in scientific circles can naturally not avoid occasionally overflowing into the field of journalism. And on several occasions, journalism has also itself attempted its own confrontation with the positivist paradigm of objectivity.

The exercise consists of continuing to retain journalism's legitimacy, but at the same either detouring around the concept of objectivity or redefining it. Journalism thus faces the problem of having to define a problematic concept and doing so in a manner which one often does with such concepts: it attempts to define the concept with the help of a bunch of equally problematic concepts, which only contributed to increasing the quagmire of problematic, undefined concepts within journalism. Paradoxically enough, journalism's attempt to confront the positivistic approach to objectivity ended up supporting the understanding and use of the positivist concept of objectivity.

A few examples of how media researchers such as Schudson, have struggled with and against their own positivist approach to objectivity can also be seen in the work of several Nordic researchers in the 1970s and early 1980s. Hence, Westerståhl (1983:403) observes: 'Maintaining objectivity in the dissemination of news can, it seems to me, most easily be defined as "adherence to certain norms or standards". Westerståhl elaborates these norms and standards into the following figure:

Figure 1. Westerståhl's Objectivety Concept, Adapted from Westerståhl (1983:405)

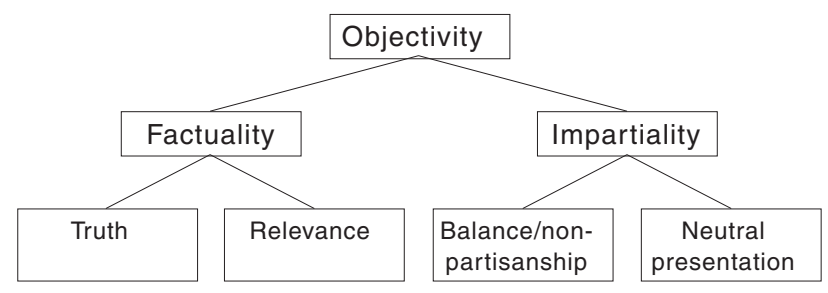

With the point of departure in the concepts of truth, relevance, balance, and neutral presentation, and with a mutual weighting of these concepts against each other, Westerståhl sets himself the task of literally measuring the level of objectivity of news coverage in eight cases. Balance is measured on a scale of +20 to -70 for each of the eight cases. Measuring balance in news coverage in this way is reminiscent of the positivist legacy.

Andrén, Hermánus et al., again in a Nordic context, also attempt to develop an operational concept of objectivity: 
We assert that a program is objective to the extent the following conditions are fulfilled:

(I) it contains true assertions.

(II) it is not misleading.

(III) it contains essential assertions.

(IV) it is thorough.

The definition of objectivity which we build upon says that a program is objective to the extent that it contains assertions which enter into a realistic view of the world (Andrén, Hemánus et al. 1979:43, emphasis in original, translated from the Danish).

But neither is this definition operational as a definition of objectivity in relation to everyday journalistic practice: for who is to determine whether the assertions are true, whether the journalistic product is misleading and contains essential assertions, and whether it is thorough? This definition also points back towards a positivist mindset, where a journalistic product must be judged as non-objective if but a single one of the above-mentioned criteria are not fulfilled.

That attempts to get around or to operationalise the concept of objectivity continue to take place can be seen in the work of Shaw et al. In a chapter entitled 'Journalists are Objective', Shaw et al. write:

When writing a story, journalists often balance the opposing sides of an issue as if their story is the only one that the public will see. Journalists do this because they want to be objective, or if that seems impossible, to be fair and balanced. This is true even though most journalists and editors have concluded that objectivity is impossible and, like magazine magnate Henry Luce, know they can only aim for fairness. Fairness and objectivity go together. Scholar Jay Rosen writes: "Objectivity is about informing the public; it tells us to worry about things like accuracy, balance and fairness" (Shaw, McCombs et al. 1997:303).

As can be seen in the quotation, objectivity and fairness are synonyms. The most interesting thing here is that fairness can be graduated: one can be more or less fair. And that since there is an equivalence between being fair and being objective, one can thus also be more or less objective. Shaw's next task, therefore, is to define how one goes about being fair as a journalist: this is done by being balanced and accurate. And the next step is thus to define what 'balanced and accurate' actually mean.

Balance is defined primarily on the basis of its opposite: a story is unbalanced when it has a preferred side, is one-sided or partisan. The assessment of whether the story is in fact unbalanced is the journalist's own. One exercises accuracy when one is careful about attributing to sources and when one as a journalist is content only to reiterate the facts.

As should be clear, it is a closed circle, where the positivist faith in the possibility of distinguishing between opinions and facts becomes the basis for the discussion. In this way, the journalistic objectivity paradigm has not moved a single inch (Hackett and Zhao 1998:113ff).

On the background of this review, it could seem that I am asserting that mainstream journalism, in contrast to the scientific areas with which it traditionally compares itself (liberal arts and social sciences) is alone in reaching backwards toward positivism in its daily work. However, this is a distorted picture: in the humanistic, social science and 
natural science research traditions, many elements of positivism continue to thrive. For example, a great part of the recent literature in scientific method profusely utilises elements of positivist thinking as a point of departure for the discussion of scientific method (Andersen 1999).

\section{Lippmann, Precision Journalism and Computer-Assisted Reporting}

Others have also attempted to rescue journalism from its legitimacy problem in connection with the concept of objectivity. Holbert and Zubric (2000) believe that it was precisely the problems of defining the concept of objectivity in operational terms which explains why journalism was drawn in (at least) three different directions up through the 1990s.

The first direction is the egalitarian public journalism. In this context, public journalism is relatively uninteresting, in that it does not really reflect upon or attempt to generalise and operationalise the concept of objectivity. Furthermore, public journalism, even though it has roots back in the early 1900s, is not a method of work especially used by journalists today, though efforts have been made to revitalize it (Bro 1998:87-101).

The second direction is the literary New Journalism. This direction is journalism's only serious attempt to break with objectivity. However, New Journalism has won only limited influence in the United States, where it was born in the 1960s and 1970s, and it has practically no influence in Denmark. New Journalism was not born out of nothing; it takes its ideas from contemporary scientific theoretical schools such as relativism, structuralism, deconstructivism and postmodernism. In the context of our discussion, these 'isms' share an opposition to the positivist objectivism paradigm. ${ }^{4}$

Whereas the positivists would assert that we are able to understand the real world in value-free terms, the opposing '-ists' would assert that this is not possible. Our view of the world is affected and masked by all kinds of learned categories, concepts and conventions. What is interesting here, therefore, is no longer what the real world looks like, but rather, what we can say about it with the help of different signs, such as language.

Whereas the positivists viewed language as a value-neutral locomotive, which could transport our understanding of the real world further, the other '-ists' see language as itself an active part in creating meaning and significance: a terrorist is a terrorist if we call him that, but he is a freedom fighter if that is what we choose to call him. In this way, we must also reject every hope of being able to represent anything objectively.

Concepts such as truth, objectivity and reality are meaningless in themselves, but interesting to study as signs. In this way, only the signs become real: the map has become more real than the landscape. This might sound pretentious, but the question of what is real and what is not is highly debatable. ${ }^{5}$ Regarding the question of how the aforementioned schools affect journalism, Andrén, Hemánus et al. (1979:11-12) observe:

This break or confrontation, which developments in scientific theory have led to, left journalism, as mentioned, with its concept of objectivity, entirely independent and undisturbed by the actual conditions and our actual insights.

But large groups of journalists and others working in the mass media followed this confrontation very closely. And they therefore went further to the second phase. It builds upon the view that objectivity does not exist and hence, that the journalist cannot be objective at all either. It is in itself a violation of the freedom of expression to want to imagine being objective. Yes, it is in fact directly false. The only thing one can trust is the individual journalist's engagement, his 
possibility to disseminate himself though his involvement (Andrén, Hemánus et al. 1979:11-12; my translation from the Danish).

The third direction is the elitist Lippmannian journalism, which in reality is not very far from mainstream journalism.

According to Lippmann, the general citizenry had neither the time, the ability nor the inclination to inform itself on important questions. Society was too complex, the power of stereotypes too great, man's immediate environment too dominant. The remedy - at least in Lippmann (1922) - had to be boards of experts who could distill the evidence and offer the residue facts (Petersen 2003:256).

These experts could be researchers or journalists themselves, to the extent that these journalists were able to acquire certain knowledge about a topic. For Lippmann, the path toward certain knowledge went via the scientific method and via professional specialization.

The idea behind this, in simplified terms, is that if the journalist borrows most of his tools from the scientific methodological toolbox, he can declare himself as having the same degree of objectivity as the sciences. Streckenfuss (1990) describes how Lippmann argued that journalism should utilise scientific methods in order to achieve objectivity:

Lippmann's use of the words objective, science, and scientific are significant. Adapting scientific method for human affairs - including journalism - was central to the thought of the decade. [...] Objective reporting, as he [Lippmann] envisioned it, would not create passive justification for the status quo, as is often assumed now. Those advancing the idea of applying scientific methods to human affairs - in all areas, not just journalism - were political liberals. They attempted to create a system of values using scientific method, borrowing from the philosophy of pragmatism expounded by William James and its variant, instrumentalism, set forth by John Dewey (Streckenfuss 1990:979).

With the clear connection to the positivist scientific ideal, one could have expected that the Lippmannian attempt to rescue the journalistic concept of objectivity would be quietly forgotten. However, this seems not to have been the case: Professor Phillip Meyer is usually attributed the honour of having invented two closely related schools of journalism: precision journalism and computer-assisted reporting (CAR). Regarding the former, Meyer writes that

A better solution is to push journalism toward science, incorporating both the powerful data-gathering and -analysis tools of science and its disciplined search for verifiable truth.

This is not a new idea. Walter Lippmann noted seventy years ago that journalism depends on the availability of objectifiable objects. [...] Scientific method offers a way to make happenings objectified, measured, and named (Meyer 1989:5).

Meyer then expresses his satisfaction that the world of science apparently welcomes journalism. He notes that Precision Journalism 'means treating journalism as if it were science, adopting scientific method, scientific objectivity, and scientific ideals to the entire process of mass communication (Meyer 1989:6).

Meyer points especially to the social science methodological apparatus including statistical data processing. Meyer's book, New Precision Journalism (1989) is fundamental as an easy-to-read version of a textbook in statistics. 
Love of statistics and the processing of great amounts of quantitative data in journalism came to mean, as mentioned, that Meyer's name became closely connected to another variant within journalism known as 'Computer-Assisted Reporting'. Meyer needed to be able to process large amounts of numerical data in order to be able to use statistics, and the computer became an obvious tool for this task. 'Ironically, [Meyer's] objective was not so much to find computer applications but to apply social science methods to journalistic practices' (Cox 2000:6).

It is therefore debatable whether there is a difference in kind or only a difference of degree between Precision Journalism and Computer-Assisted Reporting (DeFleur 1997:202-208). Computer-Assisted Reporters themselves assert that they do it differently than do other journalists, that they utilize spreadsheet, database tools and on-line resources (Cox 2000:10).

The positivist (objectivity) ideal thus seems to pervade both Precision Journalism as well as Computer-Assisted Reporting. In Denmark, Mulvad and Svith have been enthusiastic proponents of Computer-Assisted Reporting, having published a handbook of CAR in 1998 (Mulvad and Svith 1998). In their book, great emphasis is placed on instructing the reader in the use of the computer. In a newly revised edition, however, the emphasis accords more with Meyer's thinking, with far more weight now placed on scientific method, while the computer aspect is downplayed (Mulvad and Svith 2002). One of the key critiques from the research community has been that whereas the researcher is (or at least should be) aware of the scientific theoretical problems connected with applying the scientific methodological apparatus, and should continue to discuss it and criticize it some seem to believe that the journalist, with a happy 'Eureka!' galloping out onto the steppes carrying a flag emblazoned with the words 'Long Live Objectivity" in one hand and a social science methodology text book in the other.

Another manifestation of the Lippmannian ideal of forging closer ties between journalism and science is seen in the placement of the new programs in Journalism Studies at Roskilde University and at the University of Southern Denmark. While there had existed, and still exists, ties between Aarhus University and the Danish College of Journalism, which until 1998 had the monopoly on training journalists in Denmark, these ties are and were far more looser than the connection to the academic world as it has developed with the integration of journalism education into these two other Danish universities (Lund and Petersen 1999).

Furthermore, a close examination of the curricula in Odense shows two strongly Lippmannian features: the one at the Bachelor's and the other at the Master's (kandidat) level. At the undergraduate level, the student receives instruction in both social science and liberal arts methods (source criticism). These subjects, together with classes in introductory computer methods and information retrieval, are grouped, in the best Lippmannian and Meyerian understanding, under a single topic with the telling title: 'The Journalistic Tools'.

At the M.A. (kandidat) level, which is Denmark's only graduate-level training within journalism, two of the key elements are a combination of understanding scientific methods and immersion into a limited topical area (chosen by the student). The idea, in the best Lippmanian sense, is to give the journalism graduate specific expertise in a topical speciality which he can cultivate independently later on using his methodological training.

In the Journalism programs in Odense, the choice of approach to the paradigm of objectivity is thus inspired by the ideas of Lippmann and Meyer. But by virtue of the program's placement within a university and by virtue of the fact the teachers are them- 
selves researchers, who are continually confronted by the research's own discredited objectivity paradigm, it is clear that within this educational framework, we are unable to train objective journalists in a positivist sense. We have thus chosen not to attempt to define a new objectivity concept, but to pursue an understanding of the mistakes and shortcomings of the old one. This is a conscious choice, inasmuch as no one has as yet come up with a concept of objectivity that can be operationalised.

\section{Conclusions}

If one were to summarily present the journalism theoretical schools in a graphic presentation, it would look something like the illustration below:

Figure 2. The Journalistic Theoretical Map

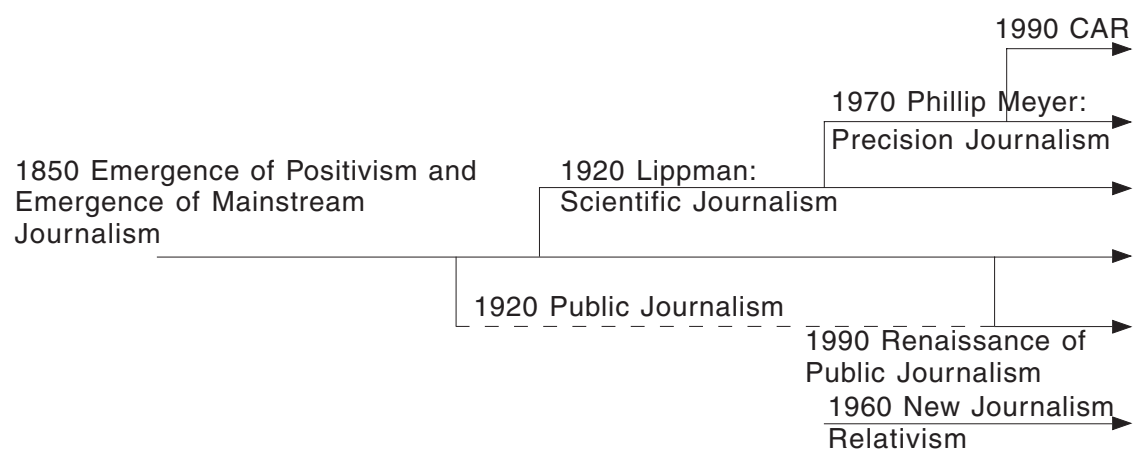

As it appears from the above figure, it is my assertion that as long as one utilises the journalistic concept of objectivity as a prism to understand what could be called journalism theory a picture like that above is revealed: The vast majority of the journalism practised today is basically positivist in its approach. Over time and on several occasions, journalism has attempted to break free of its objectivity paradigm, to free itself from positivist thinking, but only in the case of New Journalism was this attempt successful. Most contemporary journalism continues - along with the everyday thinking and much scientific work - to create close bonds to positivism.

The problem is not so much that journalism applies the positivist objectivity concept. Rather, it is that a great deal of journalism is apparently not aware of where the concept of objectivity comes from and of the problems connected to its traditional use.

Schudson (1990) is probably correct when he emphasizes how difficult it is to 'shake off positivism' in both journalism and scientific work. So even though journalism - like much research - seems to continue to find itself on the highway of positivism, and even though the previous 'exits' from this highway have shown themselves to end in blind alleys, the good news is that the struggle over journalism's concept of objectivity is certainly not yet decided; there continues to be a daily challenge for journalism to live up to its own demands for the objective dissemination of news.

Journalism is criticized, along with positivist science, for creating a much too simplified pictures of much too small bits of reality. Perhaps journalism could be advanced if it began to interest itself in other scientific theoretical directions. For example, what would today's journalism look like if it were Heidegger and Gadamer - and with them, hermeneutics (the science of interpretation) - which had provided the theoretical foun- 
dation for journalism? What kind of journalism would we have if it had been affected by thinkers such as Saussure and Eco, if - instead of positivism - it employed ideas of semiotics or structuralism?

On the one occasion when journalism proceeded to go off the highway of positivism and attempt another scientific theoretical approach, there arose a fundamentally different journalism. New Journalism never became a thundering success, probably because of the great ethical problems connected with it. But to my knowledge, no one has as yet attempted a hermeneutic, semiotic or structuralist approach to journalism. Perhaps it was actually worth a try.

\section{Notes}

1. Kjørup (2000) distinguishes between historicism and positivist and calls Ranke a historicist. This distinction is not found in P.H. Hansen (1999), who calls him a positivist. In the following, I will ally myself with Hansen, in that Ranke has the possibility to distinguish between facts and evaluations as a precondition for his work.

2. To my knowledge there are no standadised translation of the 'Erslevian' conceptual pair 'levning' and 'beretning'. Thus in the following text will use the terms 'Material evidence' for 'levning' and 'witnesses' accounts' for beretning

3. While the students are reading the overhead, I eat the apple and leave the core on the table in front of me.

4. This section builds on the work of Hackett and Zhao (1998).

5. Hansen (1999) has dealt with the phenomenon of Virtual Worlds, where people from the entire world create virtual communities on the Internet. Constructing communities of up to 680,000 users, the users create the necessary (virtual) social institutions. Hansen describes how two such users allow their representatives on the net - Avtars - to marry in a grand - internet-based - wedding ceremony.

\section{References}

Andersen, I. (1999) Den Skinbarlige Virkelighed - Om valg af samfundsvidenskabelige metoder. Frederiksberg: Samfundslitteratur.

Andrén, G.P. Hemánus, et al. (1979) Loyalitet mod virkeligheden-Objektivitet og journalistisk formidling. Copenhagen: Gyldendal.

Britannica (2003) Journalism. Encyclopcedia Britannica.

Bro, P. (1998) Journalisten som aktivist. Copenhagen: Fremads debatbøger.

Cox, M. (2000) The Development of Computer-Assisted Reporting. Newspaper division, Association for Education in Journalism and Mass Communication, University of North Carolina: Chapel Hill.

DeFleur, M.H. (1997) Computer-Assisted Investigative Reporting. Mahwah, New Jersey: Lawrence Erlbaum Associates.

Fink, J., Manniche, J.C. et al. (1996) Kildekritisk tekstsamling. Århus: Aarhus Universitetsforlag.

Hackett, R.A. \& Zhao, Y. (1998) Sustaining Democracy. Journalism and the Politics of Objectivity. Toronto: Garamond Press.

Hansen, K. (1999) Trinket og Midnight Madness blev gift - eller blev de? Cyberkultur og Teknologi, Univeristy of Copenhagen: Institut for Litteraturvidenskab, unpublished.

Hansen, P.H. (1999) En metodebog in spe?!. http://www.sdu.dk/hum/hist/phh/metmanus.htm (1999.06.25)

Hindman, E.B. (1998) Spectacles of the Poor: Conventions of Alternative News, Journalism and Mass Communication Quarterly 75(1): 177-193.

Holbert, L.R. \& Zubric, S.J. (2000) A Comparative Analysis: Objective \& Public Journalism Techniques, Newspaper Research Journal 21(4): 50-67.

Kjørup, S. (2000) Menneskevidenskaberne. Roskilde: Roskilde Universitetsforlag.

Lund, A.B. \& Petersen, J.H. (1999) Ny journalistuddannelse i Danmark, Nordicom Information 3(21): 8794.

Meyer, P. (1989) The New Precision Journalism. Bloomington: Indiana University Press.

Mulvad, N. \& Svith, F.T. (1998) Vagthundens nye bolig. Århus: Ajour.

Mulvad, N. \& Svith, F.T. (2002) Vagthund i vidensamfundet. Guide til computerstøttet journalistik. Århus: Ajour. 
Nybroe, J. \& Mylenberg, T. (2002) En anden sandhed. Om toppolitikere $i$ valgkamp. Copenhagen: Lindhardt og Ringhof.

Petersen, J.H. (2003) Lippmann Revisited. A Comment 80 Years Subsequent to 'Public Opinion'. Journalism 4(2): 249-259.

Rich, C. (2000) Writing and Reporting News: A Coaching Method. Belmont: Wadsworth Publishing Company.

Schudson, M. (1990) Origins of the Ideal of Objectivity in the Professions. Studies in the History of American Journalism and American Law 1830-1940. New York and London: Garland Publishing.

Shaw, D.L., McCombs, M. et al. (1997) Advanced Reporting. Discovering Patterns in News Events. Prospect Heights: Waveland Press.

Streckenfuss, R. (1990) Objectivity in Journalism: A Search and a Reassessment. Journalism Quarterly 67(4): 973-983.

Swartz, R. (1996) Room Service. Copenhagen: Munksgaard/Rosinante.

Thurén, T. (1986) Orientering i källkritik. Är det verkligen sant? Stockholm: Almqvist \& Wiksell Läromedel. Ufer, N. (2001) Den nøgne journalist. Århus: Ajour.

Westerståhl, J. (1983) Objective News Reporting. Communication Research 10(3): 403-424. 